\title{
Reducing Construction Disputes through Effective Claims Management
}

\author{
Hossam H. Mohamed, Ahmed H. Ibrahim, Asmaa A. Soliman* \\ Construction Engineering \& Utilities Department, Zagazig University, Zagazig, Egypt \\ *Corresponding author: asmaamadany@hotmail.com
}

Received October 01, 2014; Revised December 05, 2014; Accepted December 09, 2014

\begin{abstract}
Reducing construction disputes appears to be the main goal for many researchers in the last decay. Each of them has attempted to clearly identify the expected causes of disputes. Construction claims can be considered as a main source of disputes. This paper aims to identify the most important causes that converting construction claims into disputes. A proposed system that can help to avoid converting construction claims into disputes was provided. Factors that causing disputable claims were identified through four stages. The first stage 140 factors that causing disputable claims were collected from international literature. The second stage a brainstorming was used to reduce the number of these factors and get the most common factors causing disputable claims. Hence 31 factors were only considered. These factors were divided into three major categories: behavioral, contractual and operational matters. Through third stage, the thirty one factors were subjected to a further survey to identify their importance index (relative significance). One hundred and two interviews were conducted and their results are employed to develop an importance index score for these disputable claims causes. Furthermore, the thirty one disputable claims causes were then ranked according to their relative importance. The fourth stage, The 80/20 rule applied to the causes identified to get the eight most important causes that represented about $25 \%$ of the causes. The most important eight factors were considered as the factors that converting claims into disputes which identified as follows: 1 ) delay interim payment from client, 2) qualification of team work, 3) extension of time, 4) incomplete drawings and specification, 5) Poorly written contracts clauses, 6) change orders, 7) cooperation and communication nature among project team, 8) late supply of equipment and materials. A proposed system for avoiding converting claims into disputes was presented. Furthermore, a checklist was designed during construction stage and four actual case studies were considered and discussed.
\end{abstract}

Keywords: causes of disputes, disputable claims management

Cite This Article: Hossam H. Mohamed, Ahmed H. Ibrahim, and Asmaa A. Soliman, "Reducing Construction Disputes through Effective Claims Management." American Journal of Civil Engineering and Architecture, vol. 2, no. 6 (2014): 186-196. doi: 10.12691/ajcea-2-6-2.

\section{Introduction}

El-Wakel [6] defined "construction claims" as a claim involving a demand for payment or work related to a construction project. The claim may be either from a contractor claiming additional compensation due to changes in a contract or a client asking for compensation or additional work to be completed by a contractor not fulfilling the terms of a contract. Charehzehi and Ahankoob [2] mentioned that "a dispute can be said to exist when a claim or assertion is made by one party is rejected by the other party and that rejection is not accepted." On the other hand, incongruence among various parties in terms of their profits, requirements, and purposes which can lead them to try for the achievement of their own goals, refer to construction dispute. Overall dispute occurs when parties reject to deliver their obligations under the contract provisions. Figure 1 identifies the relationship between conflict, claims, and disputes. In addition, it shows that claims can in turn lead to disputes when settlement cannot be reached.

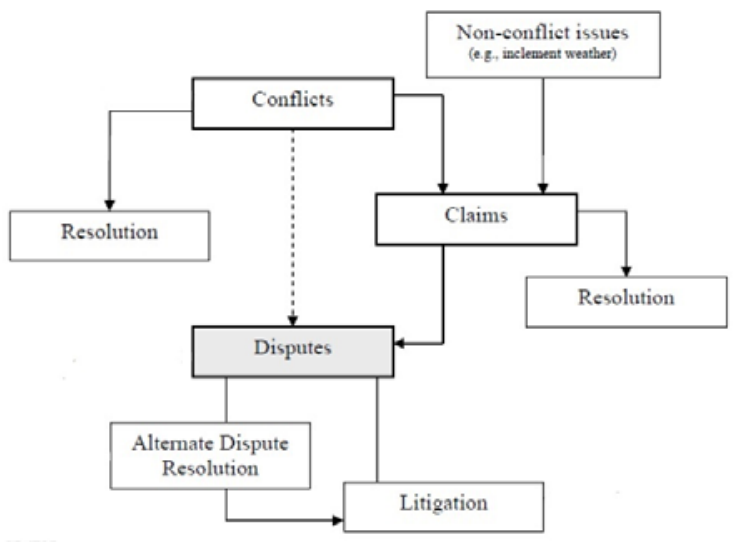

Figure 1. Conflict, Claims and disputes Adapted from Gebken [8]

El-Mesteckawi [4] founded that, there are three types of claims according to claimant compensation; time claims, cost claims and time and cost claims. The word 
"Management" means the process of dealing with or controlling people or things according to Alkass et al.[1]. But the word "Construction claim management" can be construed as the process of dealing with or controlling the seeking of consideration or change by one of the parties involved in the construction process according to Tochaiwat and Chovichien[11]. Ren et al.[12] mentioned that, the former efforts to resolve claims are mainly of two kinds: those that seek answers through claims avoidance and those that seek answers through claims management if claims cannot be avoided. The former seeks to ensure that construction project starts right, while the later aims to ensure construction project stays right. There are many sub-processes related to construction claim management. Tochaiwat and Chovichien [11] indicated seven basic procedures for claims and change order administration. They are:1) recognition and identification of change, 2) notification of change, 3) systematic and accurate documentation of change, 4) analysis of time and cost impacts of change, 5) pricing of change, 6) negotiation of claim, and 7) dispute resolution and settlement. Construction claims have many causes (controllable and uncontrollable) according to the point of view of each part of contract. Fakhr El-Deen [7] had mentioned the leading problems were caused claims concluded that, contract documents (55\%), site conditions (20\%), scheduling problems (15\%), substandard work (6\%), and contractual duty (4\%). A number of studies classify the main causes of construction claims as extension of time, variation in quantities, variation in specifications, and drawings changes. Kumaraswamy [10] determine the main (the underlying reason of the problem and if eliminated, would prevent recurrence) and proximate (immediately precedes and produces the effect) causes. Main causes include: unfair risk allocation, unrealistic time/cost/quality targets by the client, adversarial industry culture, inappropriate contract type, and unrealistic information expectations. Proximate causes identified included: inadequate brief, slow client responses, inaccurate design information, inaccurate design documentation, inappropriate contract form, inadequate contract administration, and inappropriate contractor selection.

The Alternative Dispute Resolution (ADR) can be classified into these categories: litigation, negotiation, mediation, arbitration, Partnering, Dispute Review Boards (DRB) and Mini-Trials. Negotiation is preferred by project participants as it plays an important role in preventing disputes, and keeping good relationship between project participants. Project managers consider negotiation as the most time-and energy-consuming activity in preventing disputes, Ibrahim[9]. Litigation is defined as "contest in a court of law for the purpose of enforcing a right or seeking a remedy". Contractors try to avoid litigation as possible due to high financial cost, long duration, damage to business relationships and delay of corporate resources. The most important feature of mediation is the voluntary agreement regarding the dispute with facilitation by a third party. The third party does not impose a resolution or outcome on the parties, but instead the disputing parties agree to a solution facilitated by a neutral. Arbitration is more expensive than traditional litigation but it is considered a faster technique. In arbitration, third party neutral(s) render a decision based on information submitted to him/them by the dispute parties, Ibrahim[9]. Partnering was defined by the Construction Industry Institute (CII 1996) in the United States as "a long-term commitment between two or more organizations for the purposes of achieving specific business objectives by maximizing the effectiveness of each participant resources. The DRB consists of a threemember panel chosen and approved jointly by the contractor and the owner prior to the start of construction. The primary emphasis of DRB's is to settle disputes "as soon as possible". After the panel is chosen, a third party agreement is executed by the panelists, owner and contractor. Mini-trials are generally held after other ADR mechanisms have failed, but before an actual trial. They are effective in disputes that mix factual and legal issues and are thought to promise an early "Business-Decision Settlement", El-Mesteckawi [4].

\section{Problem Statement}

Many construction projects are of long-duration and high value and foreseeing and planning for every eventuality may be impossible. Disputes are a reality in every construction project. Without a means to address them, minor issues can grow into serious disputes, with crippling consequences for project participants. The rising cost, delay and risk of litigating construction disputes has prompted the construction industry to look for more efficient ways to resolve these disputes outside of the courtroom. So the author founded that it is important for presenting a system to avoid converting construction claims into disputes as it can considered claims is the main source of disputes.

\section{Objectives}

The objectives of this research are outlined as follows:

1. Identifying the different factors that causing disputable claims from point of view of contractor.

2. Ranking these factors according to their relative importance to find out the most important factors.

3. Provide a proposed system and a comprehensive checklist to be used as a management tool for avoiding converting claims into disputes.

4. Conduct some practical case studies from actual projects.

5. Develop practical recommendations and guidelines to avoid or reduce construction disputes.

\section{Research Methodology}

The following sections present the research steps to The following sections present the research steps to achieve the objectives. An exploratory survey was carried out to identify factors that converting construction claims into construction disputes.

1. The different causes of disputable claims were gathered through a comprehensive literature review.

2. A questionnaire survey were conducted to identify the most important factors of those causing disputable claims

3. Some selected case study applications were considered. 
Through this stage one hundred and fourteen of disputable claims factors were collected from literature [13].Also a brainstorming session was conducted from eight experts to get the most important factors from one hundred and fourteen factors that identified from literature session by making a pilot survey. The pilot survey included interviews schedules with (three consultant, three contractors and two owners).In these interviews we asked these questions: 1) add any other factor that is not listed, 2) remove any of the presented factors, 3) keep factors as they are, 4) keep factors but modifying them and 5) any other suggestions. Thirty one factors were classified into three different categories as shown in Table 1. Such factors were identified based on this brainstorming exercise. These categories mainly include behavioral, contractual, and operational problems. These thirty one factors will be used to develop the first survey to get the most important factors that converting claims into disputes.

Table 1. Classification of factors which causing disputable claims, Soliman [13]

\begin{tabular}{|c|c|c|c|}
\hline NO. & Classification of factors which caused disputable claims & Frequency $(0-<10)$ & Impact (0 to 10$)$ \\
\hline & \multicolumn{3}{|c|}{ Behavioral problems } \\
\hline F1 & Cooperation and communication nature among project team & & \\
\hline F2 & Conflicting goals \& objectives of project parties & & \\
\hline F3 & No trust between the parties & & \\
\hline F4 & Qualification of team work & & \\
\hline F5 & Negotiations lacked experience & & \\
\hline F6 & Lack of team work spirit & & \\
\hline F7 & No trust on mediator & & \\
\hline \multirow[t]{2}{*}{ F8 } & Other issues in human behavior & & \\
\hline & \multicolumn{3}{|c|}{ Contractual problems } \\
\hline F9 & Delay interim payment from client & & \\
\hline F10 & Extension of time & & \\
\hline F11 & Inadequate scope definition & & \\
\hline F12 & Incomplete drawings and specification & & \\
\hline F13 & Poorly written contracts clauses & & \\
\hline F14 & Inaccurate estimating & & \\
\hline F15 & Error of pricing or costing & & \\
\hline F16 & Quality of technical specifications & & \\
\hline F17 & Planning errors accelerations & & \\
\hline F18 & Contradictory and erroneous information in the mass of documents & & \\
\hline F19 & Change Orders & & \\
\hline F20 & Inappropriate contractor selection & & \\
\hline \multirow[t]{2}{*}{ F21 } & Inadequate risk identification/allocation & & \\
\hline & \multicolumn{3}{|c|}{ Operational Problems } \\
\hline F22 & Site limitation, considering storage, access. etc & & \\
\hline F23 & Problems with authorities or neighbors affecting progress & & \\
\hline F24 & Changes in environmental regulations & & \\
\hline F25 & Force majeur & & \\
\hline F26 & Cosultant’s quality control procedures & & \\
\hline F27 & Late supply of equipment and materials & & \\
\hline F28 & Poor labor productivity & & \\
\hline F29 & Variation in quantities & & \\
\hline F30 & Bad quality of contractor's works & & \\
\hline F31 & Inadequate site or soil investigation report & & \\
\hline
\end{tabular}

\section{Questionnaire Survey}

In this survey, the causes of disputable claims are categorized into three main categories (behavioral, contractual and operational Problems). Then, the selected thirty one factors were ranked according to their relative importance to find out the most important factors of causing disputable claims. Also the sample size were computed.

\subsection{Sample Size}

According to Easterby-Smith et al. [3] which using equation (1) to compute the required sample size for unlimited population:

$$
n=\frac{2500}{E^{2}}
$$

Where:

$n$ : is the required sample size for infinite population,

$E$ : is acceptable standard error is less than $5 \%$ which used as percent

By substituting of these parameters in the equation (1), then the required sample size of this study for infinite population is 102 samples, and sample size not be less than n' which can be determined by equation (2)

$$
n^{\prime}=\frac{n}{1+\left(\frac{n}{N}\right)}
$$

Where: 
n': is the smallest sample size can be used for finite population

$N$ : is the total population size

$n$ : is the required sample size for infinite population, if population is 1.37 time $n$, so by substituting of these parameters in the equation (2), then the required limited sample size of this study for finite population is 58 samples

\subsection{Data Analysis}

One hundred and fourteen questionnaires (see appendix B) were administered to professionals and experts in different construction projects. A total of one hundred and two questionnaires representing $72.86 \%$ of the total questionnaires administered were returned. Table 2 shows details of questionnaires administered and the rate of return.

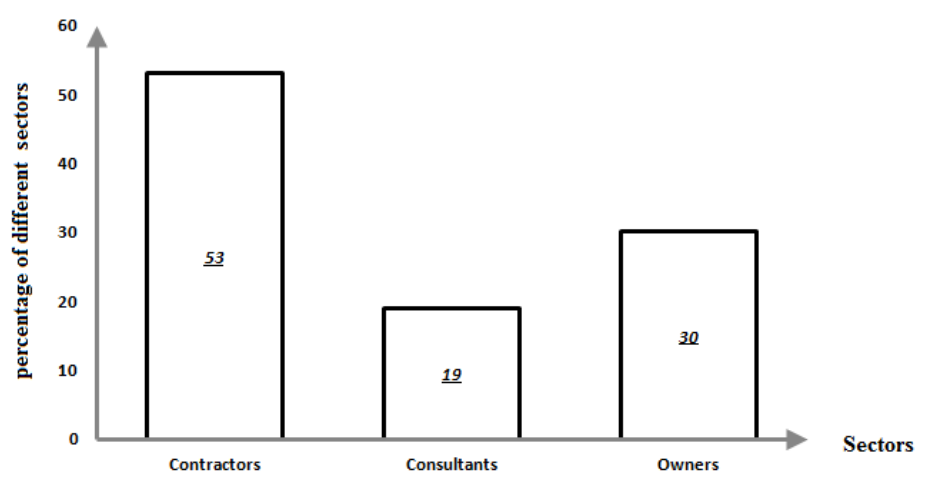

Figure 2. Classification of respondents based on their job title category, Soliman [13]

The respondents to the questionnaire were classified according to their experience Table 3. A closer inspection to Figure 3 clearly shows that about $16.67 \%$ of the respondents have experience Less than 10 years, around $36.27 \%$ have experience greater than or equals to 10 years
Table 2. Details of questionnaires administered and the rate of return, Soliman [13]

\begin{tabular}{|c|c|c|c|}
\hline $\begin{array}{c}\text { Profesionals } \\
\text { and Expets }\end{array}$ & $\begin{array}{c}\text { No.Of } \\
\text { Questionnaries }\end{array}$ & $\begin{array}{c}\text { No.Of Questionnaries } \\
\text { Returned }\end{array}$ & $\begin{array}{c}\text { \% Rate of } \\
\text { Raturned }\end{array}$ \\
\hline Contractors & 70 & 53 & 75.71 \\
\hline Consultants & 30 & 19 & 63.33 \\
\hline Owners & 40 & 20 & 75 \\
\hline Total & 140 & 102 & 72.86 \\
\hline
\end{tabular}

The respondents' job titles were classified into three categories in construction projects. The first category form contractor point of view (cost estimators, civil engineers and project managers) represented 53\%. The second category from consultant point of view represented 19\% and the third category form owner point of view represented 30\%. Figure 2 illustrates the number of each category.

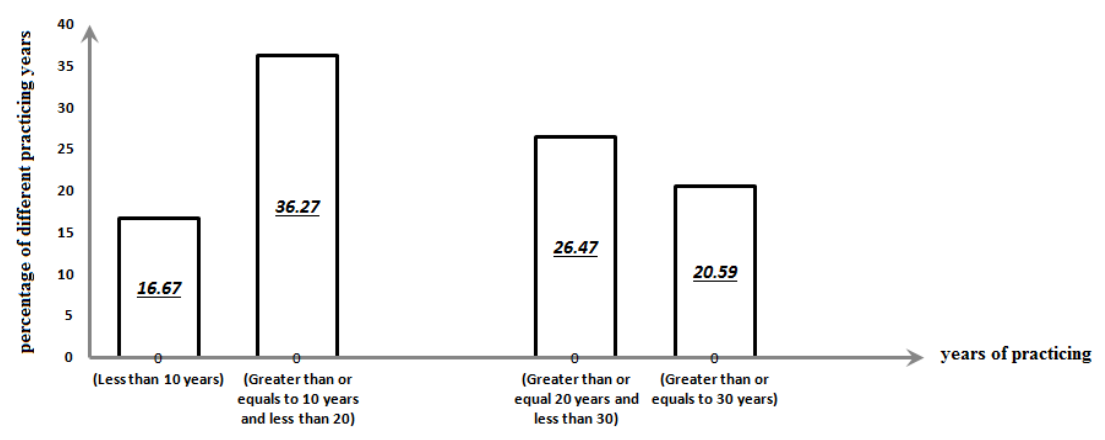

Figure 3. Classification of the surveyed experts based on their experience, Soliman [13]

Table 3. Classification of the surveyed experts based on their experience, Soliman [13]

\begin{tabular}{|c|c|c|c|c|c|}
\hline Years of Practicing & Contractor & Consultant & Owner & Total & $\%$ \\
\hline (Less than 10 years) & 9 & 2 & 6 & 17 & 16.67 \\
\hline (Greater than or equals to 10 years and less than 20) & 19 & 4 & 14 & 37 & 36.27 \\
\hline (Greater than or equals to 20 years and less than 30 ) & 14 & 5 & 8 & 27 & 26.47 \\
\hline (Greater than or equals to 30 years) & 12 & 7 & 2 & 21 & 20.59 \\
\hline TOTAL & 54 & 18 & 30 & 102 & 100 \\
\hline
\end{tabular}

Four practical case studies were carefully collected from actual projects implemented. The aim of thee studies were to demonstrate and check how actual claim procedures by contractor and owner and validate the results obtained from the data collection and analysis of questionnaire. and less than 20, around 26.47 have experience greater than or equal 20 years and less than 30 and finally, $20.59 \%$ of respondents have experience greater than or equals to 30 years.

\subsection{Most Effective Factors}

The respondents have inserted two scores in front of each factor. The first represented the frequency (probability) of occurrence of each factor. The second is the expected impact of each factor. Such analysis includes 
many important steps that can be summarized at the follows steps: First, calculate the total score of frequency and total score of impact. Second, calculate frequency and impact indexes, then calculate importance index for the previously identified thirty one factors, finally all factors are ranked in a descending order according to their importance index according to Equation (3),(4),(5),(6) and Equation (7), EL-Touny [5].

$$
\begin{aligned}
& \text { Total score of frequency } \\
& =\text { frequency of each factor }=\sum_{i=1}^{n} F_{i} \\
& \text { Total score of impact } \\
& =\text { impact of each factor }=\sum_{i=1}^{n} I_{i} \\
& \text { Frequency index (FI) }=\sum_{i=1}^{n} F_{i} /\left(N^{*} 10\right) \\
& \text { Impact index (II) }=\sum_{i=1}^{n} I_{i} /\left(N^{*} 10\right)
\end{aligned}
$$

Where:

$\mathrm{N}$ : is total number of respondents to each factor, $(\mathrm{N}=102)$. 10: represented the upper scale of the measurement.

The importance index calculated using the following formula:

$$
\text { Importance Index }=(\mathrm{FI}) *(\mathrm{II}) * 100
$$

The analysis also shows that the weight of all categories. Where (Behavioral Problems) represented 25.80\% followed by (Contractual Problems) represented 41.93\% and finally (Operational problems) represented $32.25 \%$. as shown in Figure 4 and Table 4.

It shows that eight factors under behavioral problems were considered. Moreover, instead of thirteen factors, five factors were only considered under Contractual problems. Finally, for the category of factors related to operational problems shown that the total number of factors was decreased from ten to one factor only, it demonstrates that the weight of behavioral problems, Contractual problems and factors related to operational problems are $25 \%, 62.50 \%$ and $12.50 \%$ respectively.

\begin{tabular}{|c|c|c|c|c|c|c|c|c|c|c|c|c|c|c|c|c|c|c|c|c|c|}
\hline & $\mathrm{R}$ & 1 & R2 & & 23 & $\mathrm{R}$ & & R5 & $\mathrm{R} \theta$ & $\rightarrow$ & & 101 & R1C & 02 & No. of & Total Score Of & Frequency & Total Score & Impact & Important & Rank \\
\hline No. & $\mathrm{F}$ & $\mathrm{I}$ & \begin{tabular}{|l|l|}
$\mathrm{F}$ & $\mathrm{I}$ \\
\end{tabular} & $\mathrm{F}$ & $\mathrm{I}$ & $\mathrm{F}$ & \begin{tabular}{l|l}
$\mathrm{I}$ & $\mathrm{F}$ \\
\end{tabular} & I & $\mathrm{F}$ & $\mathrm{I}$ & $\mathrm{F}$ & $\mathrm{I}$ & $\mathrm{F}$ & $\mathrm{I}$ & Responses "N" & Frequency & Index & Of Index & Index & Index \% & \\
\hline F1 & 10 & 10 & \begin{tabular}{|l|l|}
2 & 7 \\
\end{tabular} & 6 & 8 & 8 & 43 & 9 & 5 & 5 & 5 & 5 & 5 & 5 & 102 & 408 & 0.400 & 478 & 0.469 & 18.75 & 7 \\
\hline F2 & 5 & 5 & \begin{tabular}{|l|l|}
1 & 4 \\
\end{tabular} & 2 & 9 & 1 & \begin{tabular}{l|l}
1 & 7
\end{tabular} & 6 & 8 & 6 & 5 & 6 & 7 & 7 & 102 & 296 & 0.290 & 428 & 0.420 & 12.18 & 19 \\
\hline F3 & 7 & 7 & \begin{tabular}{l|l|}
4 & 6 \\
\end{tabular} & 2 & 6 & 1 & \begin{tabular}{l|l}
1 & 5 \\
\end{tabular} & 7 & 7 & 8 & 3 & 3 & 6 & 6 & 102 & 295 & 0.289 & 465 & 0.456 & 13.18 & 16 \\
\hline $\mathrm{F} 4$ & 10 & 10 & \begin{tabular}{|l|l|}
8 & 9 \\
\end{tabular} & 7 & 7 & 4 & \begin{tabular}{l|l}
8 & 6 \\
\end{tabular} & 6 & 3 & 4 & 7 & 7 & 5 & 6 & 102 & 499 & 0.489 & 548 & 0.537 & 26.28 & 2 \\
\hline F5 & \begin{tabular}{l|l}
6 \\
\end{tabular} & 6 & \begin{tabular}{|l|l|}
2 & 2 \\
\end{tabular} & 5 & 8 & 1 & \begin{tabular}{l|l}
3 & 1 \\
\end{tabular} & 1 & 5 & 6 & 1 & 7 & 9 & 9 & 102 & 257 & 0.252 & 369 & 0.362 & 9.12 & 26 \\
\hline F6 & 6 & 6 & \begin{tabular}{|l|l|}
3 & 5 \\
\end{tabular} & 8 & 9 & 2 & \begin{tabular}{l|l}
1 & 4 \\
\end{tabular} & 6 & 5 & 5 & 3 & 8 & 6 & 6 & 102 & 201 & 0.197 & 343 & 0.336 & 6.63 & 29 \\
\hline F7 & 5 & 5 & \begin{tabular}{|l|l|}
2 & 3 \\
\end{tabular} & 1 & 6 & 1 & \begin{tabular}{l|l}
15 \\
\end{tabular} & 8 & 4 & 5 & 3 & 7 & 7 & 6 & 102 & 161 & 0.158 & 332 & 0.325 & 5.14 & 30 \\
\hline F8 & 3 & 3 & \begin{tabular}{|l|l|}
3 & 4 \\
\end{tabular} & 7 & 7 & 1 & \begin{tabular}{l|l}
1 & 8 \\
\end{tabular} & 9 & 3 & 2 & 1 & 2 & 5 & 5 & 102 & 158 & 0.155 & 303 & 0.297 & 4.60 & 31 \\
\hline F9 & 7 & 9 & \begin{tabular}{|l|l|}
5 & 7 \\
\end{tabular} & 7 & 5 & 5 & $\begin{array}{l}75 \\
\end{array}$ & 7 & 7 & 6 & 3 & 6 & \begin{tabular}{|l|}
10 \\
\end{tabular} & 10 & 102 & 479 & 0.470 & 591 & 0.579 & 27.21 & 1 \\
\hline F10 & 9 & 7 & \begin{tabular}{|l|l|}
6 & 7 \\
\end{tabular} & 5 & 5 & 4 & \begin{tabular}{l|l}
8 & 7 \\
\end{tabular} & 8 & 4 & 3 & 3 & 5 & 10 & 10 & 102 & 497 & 0.487 & 543 & 0.532 & 25.94 & 3 \\
\hline F11 & 5 & 5 & \begin{tabular}{|l|l|}
3 & 4 \\
\end{tabular} & 3 & 9 & 3 & $\begin{array}{l}5 \\
5\end{array}$ & 8 & 5 & 7 & 4 & 10 & 8 & 8 & 102 & 357 & 0.350 & 479 & 0.470 & 16.44 & 13 \\
\hline F12 & 6 & 6 & \begin{tabular}{|l|l|}
7 & 8 \\
\end{tabular} & 4 & 8 & 3 & \begin{tabular}{l|l}
4 & 8 \\
\end{tabular} & 8 & 8 & 6 & 5 & 6 & \begin{tabular}{|l|}
9 \\
\end{tabular} & 9 & 102 & 489 & 0.479 & 492 & 0.482 & 23.12 & 4 \\
\hline F13 & 4 & 4 & \begin{tabular}{|l|l|}
6 & 8 \\
\end{tabular} & 3 & \begin{tabular}{|l|}
7 \\
\end{tabular} & 3 & \begin{tabular}{l|l}
5 & 8 \\
\end{tabular} & 9 & 7 & 5 & 9 & 10 & 10 & 10 & 102 & 395 & 0.387 & 525 & 0.515 & 19.93 & 5 \\
\hline F14 & 5 & 5 & \begin{tabular}{|l|l|}
3 & 4 \\
\end{tabular} & 2 & 3 & 4 & \begin{tabular}{l|l}
4 & 1 \\
\end{tabular} & 8 & 5 & 4 & 6 & 6 & 8 & 8 & 102 & 282 & 0.276 & 414 & 0.406 & 11.22 & 23 \\
\hline F15 & 4 & 6 & \begin{tabular}{|l|l|}
3 & 4 \\
\end{tabular} & 2 & 3 & 4 & \begin{tabular}{l|l}
4 & 1 \\
\end{tabular} & 8 & 8 & 8 & 1 & 2 & 9 & 9 & 102 & 263 & 0.258 & 390 & 0.382 & 9.86 & 25 \\
\hline F16 & 5 & 8 & \begin{tabular}{|l|l|}
2 & 4 \\
\end{tabular} & 6 & 8 & 6 & \begin{tabular}{l|l}
6 & 6 \\
\end{tabular} & 8 & 5 & 4 & 2 & 7 & 7 & 7 & 102 & 387 & 0.379 & 457 & 0.448 & 17.00 & 12 \\
\hline F17 & 7 & 7 & \begin{tabular}{|l|l|}
4 & 6 \\
\end{tabular} & 3 & 6 & 3 & \begin{tabular}{l|l}
5 & 4 \\
\end{tabular} & 9 & 6 & 7 & 2 & 4 & 6 & 6 & 102 & 304 & 0.298 & 415 & 0.407 & 12.13 & 20 \\
\hline F18 & 6 & 9 & \begin{tabular}{|l|l|}
3 & 4 \\
\end{tabular} & 3 & 6 & 2 & \begin{tabular}{l|l}
3 & 1 \\
\end{tabular} & 4 & 9 & 8 & 4 & 5 & 7 & 7 & 102 & 292 & 0.286 & 418 & 0.410 & 11.73 & 21 \\
\hline F19 & 3 & 6 & \begin{tabular}{|l|l|}
3 & 4 \\
\end{tabular} & 6 & 6 & 2 & \begin{tabular}{l|l}
3 & 5 \\
\end{tabular} & 8 & 3 & 4 & 4 & 8 & 9 & 9 & 102 & 403 & 0.395 & 505 & 0.495 & 19.56 & 6 \\
\hline F20 & 5 & 6 & \begin{tabular}{|l|l|}
3 & 6 \\
\end{tabular} & 2 & 8 & 3 & $\begin{array}{l}5 \\
5\end{array}$ & 10 & 7 & 9 & 3 & 3 & 8 & 8 & 102 & 366 & 0.359 & 512 & 0.502 & 17.91 & 8 \\
\hline F21 & 7 & 7 & \begin{tabular}{|l|l|}
3 & 5 \\
\end{tabular} & 7 & 10 & 2 & \begin{tabular}{l|l}
4 & 1 \\
\end{tabular} & 1 & 8 & 8 & 8 & 1 & 7 & 7 & 102 & 306 & 0.300 & 453 & 0.444 & 13.32 & 15 \\
\hline F22 & 2 & 4 & \begin{tabular}{|l|l|}
4 & 6 \\
\end{tabular} & 5 & 7 & 5 & \begin{tabular}{l|l}
6 & 5 \\
\end{tabular} & 8 & 5 & 3 & 2 & 5 & 5 & 3 & 102 & 299 & 0.293 & 406 & 0.398 & 11.67 & 22 \\
\hline F23 & 7 & 9 & \begin{tabular}{|l|l|}
3 & 4 \\
\end{tabular} & 6 & 5 & 3 & \begin{tabular}{l|l}
3 & 5 \\
\end{tabular} & 8 & 6 & 5 & 2 & 6 & 4 & 3 & 102 & 264 & 0.259 & 435 & 0.426 & 11.04 & 24 \\
\hline F24 & 5 & 5 & \begin{tabular}{|l|l|}
3 & 4 \\
\end{tabular} & 2 & 5 & 1 & \begin{tabular}{l|l}
1 & 1 \\
\end{tabular} & 1 & 5 & 4 & 3 & 5 & 5 & 5 & 102 & 224 & 0.220 & 372 & 0.365 & 8.01 & 27 \\
\hline F25 & 3 & 8 & \begin{tabular}{|l|l|}
2 & 5 \\
\end{tabular} & 1 & 9 & 1 & \begin{tabular}{l|l}
1 & 1 \\
\end{tabular} & 1 & 9 & 3 & 3 & 4 & 3 & 7 & 102 & 170 & 0.167 & 424 & 0.416 & 6.93 & 28 \\
\hline F26 & 6 & 10 & \begin{tabular}{|l|l|}
4 & 7 \\
\end{tabular} & 2 & 6 & 1 & \begin{tabular}{l|l}
1 & 1 \\
\end{tabular} & 8 & 4 & 8 & 3 & 4 & 6 & 7 & 102 & 311 & 0.305 & 451 & 0.442 & 13.48 & 14 \\
\hline F27 & 7 & 9 & \begin{tabular}{l|l|}
4 & 6 \\
\end{tabular} & 2 & 8 & 4 & $\begin{array}{ll}46 \\
\end{array}$ & 9 & 4 & 3 & 4 & 4 & 8 & 8 & 102 & 385 & 0.377 & 484 & 0.475 & 18.01 & 9 \\
\hline F28 & 6 & 8 & \begin{tabular}{|l|l|}
5 & 8 \\
\end{tabular} & 5 & 7 & 3 & \begin{tabular}{l|l}
44 & 7 \\
\end{tabular} & 8 & 6 & 5 & 3 & 4 & 7 & 9 & 102 & 288 & 0.282 & 441 & 0.432 & 12.21 & 18 \\
\hline F29 & 3 & 5 & \begin{tabular}{|l|l|}
5 & 8 \\
\end{tabular} & 5 & 7 & 4 & \begin{tabular}{l|l}
44 & 7 \\
\end{tabular} & 8 & 8 & 7 & 4 & 4 & 8 & 10 & 102 & 312 & 0.306 & 414 & 0.406 & 12.42 & 17 \\
\hline F30 & 5 & 7 & \begin{tabular}{|l|l|}
3 & 5 \\
\end{tabular} & 3 & 7 & 4 & \begin{tabular}{l|l}
5 & 5 \\
\end{tabular} & 9 & 7 & 7 & 6 & 6 & \begin{tabular}{|l|}
7 \\
\end{tabular} & 9 & 102 & 359 & 0.352 & 507 & 0.497 & 17.49 & 10 \\
\hline F31 & 6 & 6 & \begin{tabular}{|l|l|}
6 & 9 \\
\end{tabular} & 5 & 7 & 2 & \begin{tabular}{l|l}
44 & 7 \\
\end{tabular} & 8 & 4 & 5 & 5 & 9 & \begin{tabular}{|l|}
8 \\
\end{tabular} & 9 & 102 & 338 & 0.331 & 535 & 0.525 & 17.38 & 11 \\
\hline
\end{tabular}

Table 4. Factors converting claims to disputes before and after ranking, Soliman [13]

\begin{tabular}{|c|c|c|c|c|c|}
\cline { 3 - 6 } \multicolumn{2}{c|}{} & \multicolumn{2}{c|}{$\begin{array}{c}\text { All factors before } \\
\text { ranking }\end{array}$} & \multicolumn{2}{c|}{$\begin{array}{c}\text { Factors after } \\
\text { ranking }\end{array}$} \\
\hline No & Category & Sum & Weight & Sum & Weight \\
\hline 1 & Behavioral problems & 8 & $25.80 \%$ & 2 & $25 \%$ \\
\hline 2 & Contractual problems & 13 & $41.93 \%$ & 5 & $62.50 \%$ \\
\hline 3 & Operational problems & 10 & $32.25 \%$ & 1 & $12.50 \%$ \\
\hline \multirow{2}{*yyyyy}{} & Total & 31 & $100 \%$ & 8 & $100 \%$ \\
\cline { 2 - 6 }
\end{tabular}

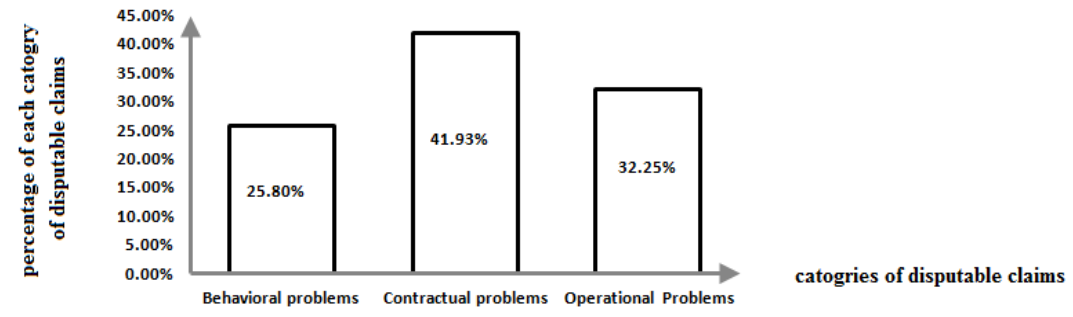

Figure 4. Classification of factors causing disputes, Soliman [13]

Table 5. Factors which causing construction claims, Soliman [13] 
The calculated importance indices are shown also in Table 5. All factors were then ranked according to their importance indices.

\section{Results and Analysis}

Figure 5 illustrates the most important eight factors that converting construction claims into disputes in the Egyptian construction market as a result of this research. This result indicated that delay interim payment from client was ranked in the first position with a (R.II) $27.27 \%$ as the most important cause of disputable claim because it may result in a financial problem to the contractor cash flow, qualification of team work (interpersonal skills, history together, experience in construction law, practices and management and etc,.), was ranked in the second position with a (R.II) $26.28 \%$. This due to lack of interpersonal skills, low balance among project parties as a strong party may have advantage when it comes time to settle disputes. This tends to alienate one or more parties and does not help to solve disagreements and Poor team building. etc. Extension of time was ranked in the third position with a (R.II) $25.94 \%$, the construction of a project or a part of the project is not completed within the time period originally intended and as specified in the contract. This can occur due to Failure to obtain necessary permits for the work, poor workmanship and site conditions which differ from what was expected, etc. Incomplete drawings and specification was ranked in the fourth position with a
(R.II) 23.12\%. This means that, drawings and specifications are important components for tendering process. Incomplete drawings and specifications lead to improper studying for the project quantity and price. The contractor should immediately report the deficiencies founded in the drawings and specifications to the owner otherwise, disputes will be increased later during construction stage between contract parties Poorly Written Contracts clauses were ranked in the fifth position with a (R.II) 19.93\%. Poorly written contract clauses are incomplete because it is too costly to describe all the relevant contingencies and the exact behavior of the contracting parties, variation order s by owner was ranked in the six position with a (R.II) $19.56 \%$, this means that, frequent changes caused by owner in design drawings, material type, addition and/or omission from the contract original scope, and modification of works during construction stage lead to increase project duration and costs which is highly undesirable for any of the contracting parties, cooperation and communication nature among project team was ranked in the seven position with a(R.II) 18.75\%, good communication needs to be established from the start in order to prevent the problems escalating into disputes, late supply of equipment and materials was ranked in the eight position with a (R.II) $18.01 \%$. this due to lack of clarity from supplier market, poor quality of material in construction and Shortage of construction materials in market which causes delays to project then lead to construction disputes.

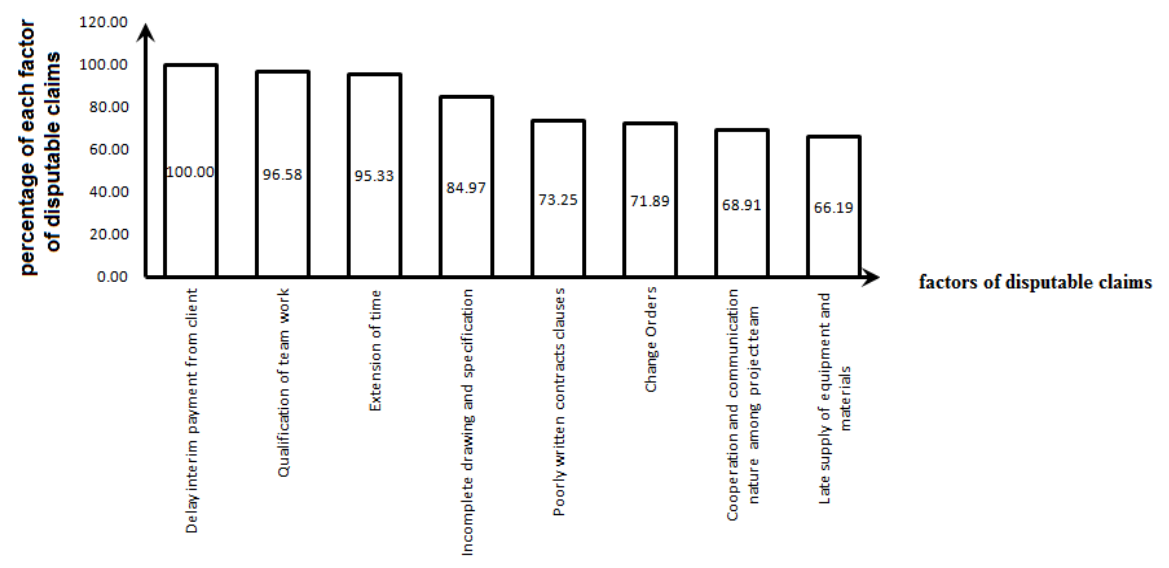

Figure 5. The most important eight factors that converting claims to disputes, Soliman [13]

\section{Proposed System for Avoiding Construction Disputable Claims}

The contractor, the owner and consultant should be aware about the construction claim management and understand the most factors which converting construction claims into disputes. The authors developed a proposed effective claim management system, such system is based on the collected data in literature and current research results from actual construction projects. The proposed system can help to avoid disputable claims by studying the main causes and avoidance of each factor from eight disputable claims factors. The main causes and avoidance of each factor in three stages of project: before, during and after construction were studied, where a system was presented for during construction only in this research. From applying checklist as shown in appendix (C), causes of disputable claims during construction stage can be selected. Then, by conversance these causes; appendix (B) can be applied to avoid it. The objective of the presented checklist is to be used as a tool for determining potential problems that can help to identify area of concerns and how avoid converting claims into disputes. Also the system for before and after construction stage was designed as the same sequence of the proposed system during construction stage.

\section{Case Studies}

Four actual case studies discussing factors which converting claims into disputes which were collected from actual projects implemented, and these cases were 
collected from a contractor's company. The aim of collecting these cases is to study the causes which affecting construction disputes and compare them with the results obtained from questionnaire; to validate the survey finding. Upon reviewing the claim reports submitted by contractor or Owner for each case study, the researcher filled the checklist presented in appendix (C). Following sub-sections describe these cases.

\subsection{First Case Study}

A contract was signed between the defendant (owner) and the claimant (contractor) for the excuting a multibuilding story with a duration 24 months, and for a contact cost of 9 million pounds. The contractor began the work once mobilized to the site. Then, the project was delayed for these reasons:

1. During the implementation of the foundations according to executive Drawing and soil borings found that the water level is two meters from the surface of the soil which is very heavy as the building is near to River Nile.

2. Redesign of the foundations and columns which result of changing the thickness of the replacement layer.

3. Works has been increased and request the establishment of a separate building contains: two rooms of the generator transformers, rooms reserve a private and room to pressure dilute

4. After the completion of the implementation of the project the owner added to the work of central air conditioning for whole the building.

Due to these delays, the defendant (owner) agreed to extend the project duration which resulted in a total extension of time 36 months. But the defendant (owner) refused to give the claimant (contractor) his rights for any compensation. After that, the contractor resorted to a mediation to solve this problem. And the total amount of project about 24 million pounds.

\subsection{Second Case Study}

A contract was signed between the defendant (owner) and the claimant (contractor) for the executing of a multibuilding story with duration 16 months, and for a contact cost of 22343000 pounds. The contractor began work once mobilized to the site. Then, the project was delayed for these reasons:

1. Delays in the procurement of certain devices such as air conditioning

2. Modifications from the owner at the Hall of conferences

3. Late a approval of shop drawings, technical specification and material samples

4. Several design changes were introduced by the owner

5. Events of Revolution of 25 January

6. Allowing other contractors to work on the project site in a way that interferes with the main contractor's work

7. Client disagreement on valuation of the work done.

Due to these delays, the defendant (owner) agreed to extend the project duration which resulted in a total extension of time 33 months. Also the defendant (owner) agreed to give the claimant (contractor) his rights for any compensation. And the total amount of project about 25755656 pounds.

\subsection{Third Case Study}

A contract was signed between the defendant (owner) and the claimant (contractor) for Cooling turbines of Electricity Station at Ain El Sokhna. this project is for the Supply and installation of 3 Fiber Glass Pipe diameter 3 meters long in the Red Sea and 400 meters long Ain Sokhna. Addition to construction a built downstream and three buildings of the outlet. also inside the main pipes there is a linear pipes diameter four and eight inches of chlorine extends even built downstream. The project duration was 18 months, and for a contact cost was 375 million pounds. The contractor commenced work once mobilized to the site. However, the project was delayed for the these reasons:

1. The existence of a defect in the design of connections for chlorine lines, which led to the failure of many of testing connections.

2. Late supply of pipes by the company which responsible for the supply .

3. Spent more time to replace or repair pipes by subcontractors

4. Insufficient information and poor documentation on work progress.

Due to these delays, the defendant (owner) agreed to extend the project duration which resulted in a total extension of time 24 months. Also the defendant (owner) agreed to give the claimant (contractor) his rights for any compensation. And the total amount of project about 383 million pounds.

\subsection{Fourth Case Study}

A contract was signed between the defendant (owner) and the claimant (contractor) for the executing building in 10 th Ramadan city. This project with a duration 18 months, and for a contact cost of 4738786.9 pounds. The contractor began work once mobilized to the site. Then, the project was delayed for these reasons:

1. Late supply of materials to the site

2. Reworks from subcontractors

3. team work not qualified

4. Due 25 Jan Revolution the client delayed interim payment to contractors

5. Low experience for the certain a activities to be constructed.

Due to these delays, the defendant (owner) agreed to extend the project duration which resulted in a total extension of time 30 months. Also the defendant (owner) agreed to give the claimant (contractor) his rights for any compensation. And the total amount of project increased by one million pounds.

\section{Analysis of Case Studies Outcomes}

From analyzing the causes of disputable claims in the first case study, we founded the causes as follow: contradictory and erroneous information in the mass of documents, change orders, extension of time, poorly written contracts clauses and incomplete drawings and specification. Also from analyzing the causes of 
disputable claims in the second case study, we founded the causes as follow : force majeure (25 Jan, revolution), bad quality of contractor's works, contradictory and erroneous information in the mass of documents, change orders, extension of time, Poorly written contracts clauses and Incomplete drawings and specification and quality of technical specifications. Also from analyzing the causes of disputable claims in the third case study, we founded the causes as follow: low experience with the type of project undertaken, bad quality of contractor's works, contradictory and erroneous information in the mass of documents, change orders, extension of time, poorly written contracts clauses and incomplete drawings and specification and quality of technical specifications. Also from analyzing the causes of disputable claims in the fourth case study, we founded the causes as follow: delay payment from client, bad quality of contractor's works, contradictory and erroneous information in the mass of documents, change orders, extension of time, poorly written contracts clauses and incomplete drawings and specification. Also from applying checklist in four case studies, this result indicated that extension of time was ranked in the first position with 12 times out of 39 (about $30.76 \%$ ) as the most important cause of disputable claims because it may result in failure to provide adequate access to the site and failure of the consultant to provide or approve drawings in reasonable time, owner interference, defective or insufficient plans and specification, delay in contractor's claims settlement, unavailability of labor, material and poor site management, in the second position delay interim payment from client with 8 times out of 39 (about $20.51 \%$ ) because it may result in insufficient information and poor documentation on work progress, client's ineffective utilization of funds, poor cash flow because of lake of proper process implementation, client's poor financial and business management, clients' failure to cultivate a good payment attitude among its employees by wrongfully withholding the payment, clients' disagreeing on the valuation of work done. in the third position qualification of team work with 8 times out of 39 (about $15.38 \%$ ) because it may result in Unrealistic owner's expectation, lack of experience in construction law, practices and management, low experience with type of project undertaken and poor team building. In the fourth position late supply of equipment and materials 4 times out of 39 (about $10.25 \%$ ) because it may result in Shortage of construction materials in market, unpunctually material delivery, Poor quality of material in construction, spend more time to replace or repair equipment parts by sub suppliers, Tight contact with supplier, changes in material types and specifications, damage of sorted material while they are needed urgently, and low level of equipment-operator's skill. In the fifth position incomplete drawings and specification and variation orders by owners with 3 times out of 39 (about $7.69 \%$ ) because it may result in misunderstanding of shop drawings, errors, rework and demolition in the sixth position poorly written contracts clauses with 2 times out of 39 (about $7.69 \%$ ) because it may result in diverse interpretations of contract terms, other owners are more receptive to sharing the risk and use less restrictive language in their general conditions, and owners are not interested in dealing with increased cost. In the last position cooperation and communication nature among project team with 1 times out of 39 (about $2.56 \%$ ) because it may result in using the site in a way that impedes the contractor's work at the site by owner, allowing other contractors to work on the project site in a way that interferes with the contractor's work.

\section{Conclusion and Recommendations}

Construction claims have such high impacts on the projects 'cost and time that the contractors and owners should establish the effective claims management in their organization.The objective of this paper to make effective claims management to reduce risks of construction disputes.The identification of disputable claims factors which affecting construction disputes can assist to reduce and avoid construction disputes. The $80 / 20$ rule applies to these causes indicated that the most important eight causes represent about $25 \%$ of causes.The most disputable claims factors are:extension of time, delay interim payment from client,qualification of team work, variation order s by owner, poorly Written contracts, late supply of equipment and materials, incomplete drawings and specification and cooperation and communication nature among project team.Also a system was presented that can help to avoid disputable claims by studying the main causes and avoidance of each factors from eight disputable claims factors.we studied the main causes and avoidance of each factors in three stages of project :before,during and after construction,where a system for the construction stage only was presented in this research. From applying checklist as shown in appendix (C), causes of disputable claims during construction stage can be selected. Then, by conversance these causes; appendix (B) can be applied easily to aviode it.

- It is recommended to avoid the disputable claims the following:

- Owners need to effectively manifest their needs and requirements before designs are conducted.

- Consultants should give especial care to designs and provide quality designs that have been reviewed.

- Delay interium payment by client is considered as the most causing disputable claims, unlike the other issues in human behavioral such as cheating and deception is the least causing disputable claims.

- consultants need to give special care to the review and approval of shop drawings.

- Make sure that everyone understands the contractual notice provision.

- Owners, contractors, designers, etc must be aware of the notice provision in contract document.

- Recognize that a "risk-sharing" philosophy will probably produce the lowest overall project cost for the owner and maximum profit to the Contractor.

\section{References}

[1] Alkass, S., Mazerolle, M. and Harris, F., "Construction delay analysis techniques. ", Journal of ConstructionManagement and Economic, Vol. 14, March 1995, pp 375-394.

[2] Charehzehi, A. and Ahankoob, A, "The use of analytical approach for the selection of dispute resolution". Department of Structure and Materials, Faculty of Civil Engineering, University of Teknologi Malaysia (UTM), Johor Bahru, Johor, Malaysia, 2013. 
[3] Easterby-Smith, M., Thorpe, R. and lowe, A, " Management research: a introduction ", SAGE publications Ltd, 2002.

[4] El-Mesteckawi, L, "Managing construction disputes in Egypt", M.Sc. Thesis, Cairo University, Egypt, 2007.

[5] EL-Touny, A., "Estimating contingency cost for highway construction projects". M.Sc.Thesis, Zagazig University. Egypt, 2014.

[6] El-Wakel, E., "Developing computerized construction claims decision support system to raie ability of construction management team against claims". M.Sc.Thesis, Zagazig University, Egypt, 2006.

[7] Fakhr El-Deen, Sh., "Efficiency of construction claim management process." M.Sc. Thesis, Arab Academy for Science Technology and Maritime Transportation, Egypt, 2012.

[8] Gebken, R., "Quantification of transactional dispute resolution costs for the U.S. construction industry", PHD, thesis, The University of Texas at Austin, 2006.
[9] Ibrahim, M., "Estimating minimum acceptable construction claim amounts in negotiation process." M.Sc.Thesis, Cairo University, 2007.

[10] Kumaraswamy, M., "Conflicts, claims and disputes", Journal of Engineering, Construction and Architectural Management", 4(2), 1997, pp.95-111.

[11] Tochaiwat, K. and Chovichien, V., "Problems of clients' construction claim management in Thailand". Department of Civil Engineering, Chulalongkorn University, Bangkok, Thailand, 2007.

[12] Ren, Z., Anumba, C. and Ugwu, O., "Towards a multi-agent system for construction claims negotiation", Department of Civil \& Building Engineering, University of Loughborough, Loughborough, UK, 2000.

[13] Soliman, A.A. (Incomplete), "Effective claims management to reduce risks of construction disputes". M.Sc.Thesis, Zagazig University, Egypt.

\section{Appendix (A)}

\section{Questionnaire Survey}

In this survey, the causes of construction disputes are categorized into three main categories:

\section{Behavioral Problems \\ 2. Contractual Problems \\ 3. Operational Problems}

Note:

Please give a rank number for each factor to reflect its significance, Time as Frequency, where 0 indicates lack of factor's Frequency and from 1 to10 indicates no. of Frequency for each factor, Time as factor Severity, where 0 indicates lack of factor and from 1 to 10 indicates to value of factor Severity

\section{1- Behavioral Factors}

1-1 Cooperation and communication nature among project team

1-2 Conflicting goals\&objectives of project parties

1-3 No trust between the parties.

1-4 Qualification of team work

1-5 Negotiations lacked experience

1-6 Lack of team work spirit

1-7 No trust on mediator.

1-8 Other issues in human behavior
Frequency

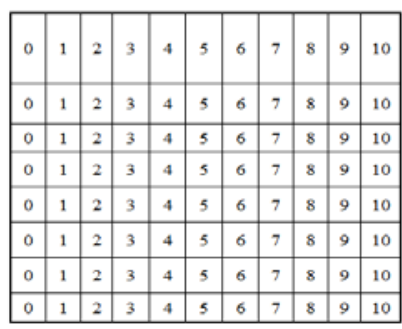

Severity

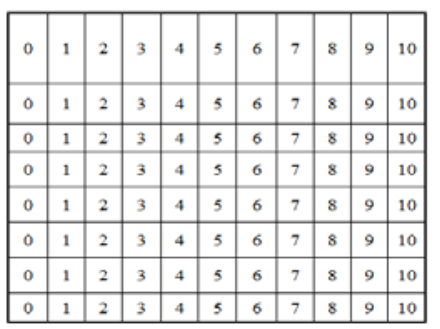

Please specify any additional problems and their frequency and severity numbers:

\section{2- Contractual Factors}

2-1 Delay interim payment from client 2-2 Extension of time 2-3 In adequate scope definition

2-4 In complete drawings and specification

2-5 poorly written contracts clauses

2-6 In accurate estimating.

2-7 Error of pricing or costing

2-8 Quality of technical specifications

2-9 Planning errors acceleration to regain schedule

2-10 Contradictory and erroneous information in the mass of documents.

2-11 Variation orders by client

2-12 Inappropriate contractor selection.

2-13 In adequate risks identification/allocation
Frequency

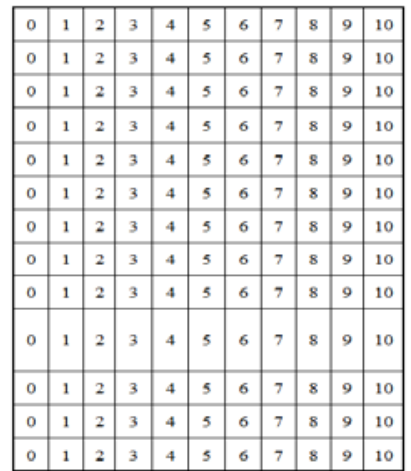

Severity

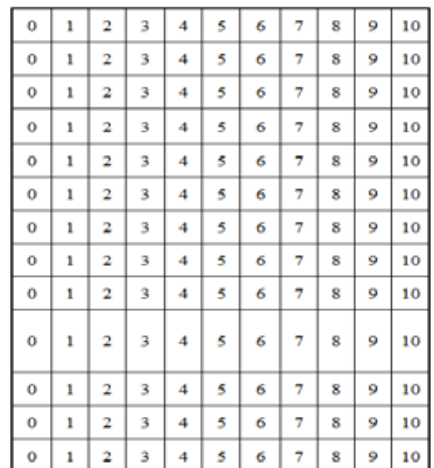

Please specify any additional problems and their frequency and severity numbers:

3 - Operational Factors

3-1 Site limitation, considering storage, access.etc 3-2 problems with authorities or neighbors

3-3 Changes in environmental regulations

3-4 Force majeur

3-5 Cosultant's quality control procedures

3-6 late supply of equipment and materials

3-7 Poor labor productivity

3-8 Variations in quantities

3-9 Bad quality of contractor's works

3-10 inadequate site or soil investigation report

Frequency

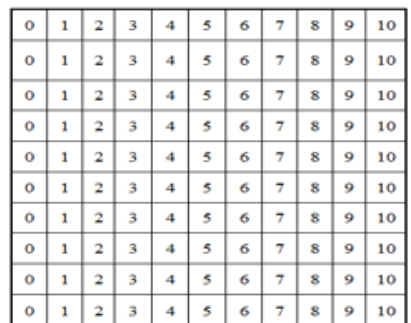

Severity

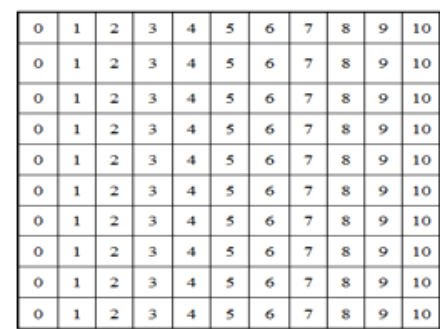

Please specify any additional problems and their frequency and severity numbers: 


\section{Appendix (B)}

The proposed system for avoiding construction disputable claims during construction, soliman[13].

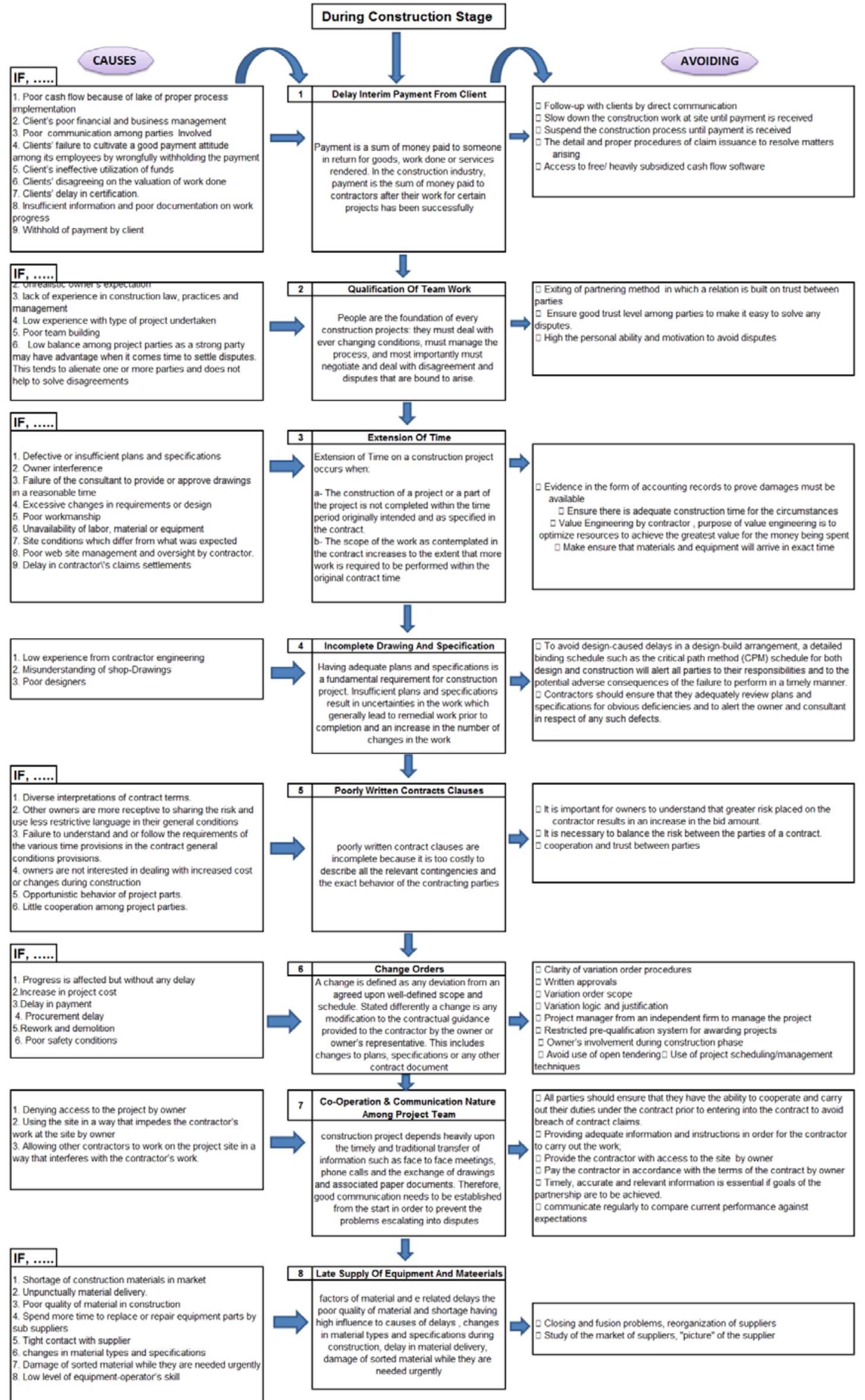




\section{Appendix (C)}

Applied Checklist for four actual case studies occurred during construction, soliman [12].

\begin{tabular}{|c|c|c|c|c|c|c|c|}
\hline & \multirow{3}{*}{ Factors Which Converting Claims Into Disputes (Description and Causes) } & \multicolumn{4}{|c|}{ During Construction Stage } & \multirow{3}{*}{$\begin{array}{c}\text { total } \\
\text { ferquency }\end{array}$} & \multirow{3}{*}{$\begin{array}{c}\text { percentage } \\
\%\end{array}$} \\
\hline & & \multicolumn{4}{|c|}{ frequency of causes affecting construction disputes } & & \\
\hline & & Case study \#1 & case study \#2 & case study \#3 & case study\# 4 & & \\
\hline 1 & \multicolumn{5}{|l|}{ Delay Interim Payment From Client } & \multirow{11}{*}{8} & \multirow{11}{*}{20.51} \\
\hline 宫 & \multicolumn{5}{|c|}{$\begin{array}{l}\text { Payment is a sum of money paid to someone in return for goods, work done or services rendered. In the construction industry, payment is the sum of money paid to contractors } \\
\text { after their work for certain projects has been successfully }\end{array}$} & & \\
\hline \multirow{9}{*}{ 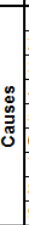 } & 1. Poor cash flow because of lake of proper process implementation & 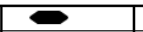 & $\sigma$ & 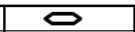 & 0 & & \\
\hline & 2. Client's poor financial and business management & $\sigma$ & 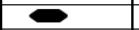 & $\bar{\sigma}$ & 0 & & \\
\hline & 3. Poor communication among parties Involved & $\sigma$ & $\sigma$ & $\sigma$ & $\sigma$ & & \\
\hline & 4. Clients' failure to cultivate a good payment attitude among its employees by wrongfully withholding the payment & $\sigma$ & $\sigma$ & $\sigma$ & $\sigma$ & & \\
\hline & 5. Client's ineffective utilization of funds & $\sigma$ & $\sigma$ & $\sigma$ & $\sigma$ & & \\
\hline & 6. Clients' disagreeing on the valuation of work done & $\sigma$ & 0 & $\sigma$ & $\sigma$ & & \\
\hline & 7. Clients' delay in certification. & $\sigma$ & $\sigma$ & $\sigma$ & 0 & & \\
\hline & 8. Insufficient information and poor documentation on work progress & 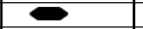 & 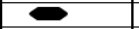 & $\sigma$ & $\sigma$ & & \\
\hline & 9. Withhold of payment by client & $\sigma$ & $\sigma$ & $\sigma$ & $\sigma$ & & \\
\hline 2 & Qualification Of Team Work & & & & & & \\
\hline 㝘. & $\begin{array}{r}\text { People are the foundation of every construction projects: they must deal with ever changing conditions, must ma } \\
\text { with disagreement and disputes that are bound to a }\end{array}$ & $\begin{array}{l}\text { inage the process, } \\
\text { irise. }\end{array}$ & s, and most impor & ortantly must neg & otiate and deal & & \\
\hline & 1. Dishonesty of project consultants and contractors & $\sigma$ & $\sigma$ & $\sigma$ & $\sigma$ & & \\
\hline & 2. Unrealistic owner's expectation & $\sigma$ & 0 & 0 & $\sigma$ & 6 & 15.38 \\
\hline 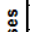 & 3. lack of experience in construction law, practices and management & $\sigma$ & $\sigma$ & 0 & $\sigma$ & & \\
\hline$\stackrel{\infty}{=}$ & 4. Low experience with type of project undertaken & $\sigma$ & $\sigma$ & 0 & 0 & & \\
\hline లొ & 5. Poor team building & $\sigma$ & $\sigma$ & $\sigma$ & 0 & & \\
\hline & $\begin{array}{l}\text { 6. Low balance among project parties as a strong party may have advantage when it comes time to settle } \\
\text { disputes. This tends to alienate one or more parties and does not help to solve disagreements }\end{array}$ & $\varnothing$ & $\varnothing$ & $\varnothing$ & $\varnothing$ & & \\
\hline 3 & $\begin{array}{ll} & \text { Extension Of Time } \\
\end{array}$ & & & & & & \\
\hline & $\begin{array}{l}\text { Extension of Time on a construction project occurs when: } \\
\text { a- The construction of a project or a part of the project is not completed within the time period originally intended ar } \\
\text { b- The scope of the work as contemplated in the contract increases to the extent that more work is required to be }\end{array}$ & $\begin{array}{l}\text { hd as specified in } t \\
\text { performed within th }\end{array}$ & $\begin{array}{l}\text { the contract. } \\
\text { the original contra }\end{array}$ & ract time & & & \\
\hline & 1. Defective or insufficient plans and specifications & $0 \quad$ & $\sigma \quad$ & $\sigma$ & 0 & & \\
\hline & 2. Owner interference & $\sigma$ & 0 & $\sigma$ & $\sigma$ & & \\
\hline & 3. Failure of the consultant to provide or approve drawings in a reasonable time & 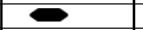 & 0 & $\sigma$ & $\sigma$ & 12 & 30.76 \\
\hline \& & 4. Excessive changes in requirements or design & $\sigma$ & $\sigma$ & $\sigma$ & $\sigma$ & & \\
\hline 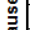 & 5. Poor workmanship & $\sigma$ & $\sigma$ & $\sigma$ & 0 & & \\
\hline ઠొ & 6. Unavailability of labor, material or equipment & $\sigma$ & ठ & $\sigma$ & 0 & & \\
\hline & 7. Site conditions which differ from what was expected & 0 & $\sigma$ & 0 & 0 & & \\
\hline & 8. Poor web site management and oversight by contractor. & $\sigma$ & 0 & $\sigma$ & $\sigma$ & & \\
\hline & 9. Delay in contractorl's claims settlements & $\sigma$ & $\boldsymbol{\sigma}$ & $\sigma$ & $\sigma$ & & \\
\hline 4 & Incomplete Drawinds And Specification & & & & & & \\
\hline 㝘. & $\begin{array}{l}\text { Having adequate plans and specifications is a fundamental requirement for construction project. Insufficient pl } \\
\text { generally lead to remedial work prior to completion and an increase in the nu }\end{array}$ & $\begin{array}{l}\text { ans and specificat } \\
\text { Imber of changes i }\end{array}$ & $\begin{array}{l}\text { ations result in unc } \\
\text { in the work. }\end{array}$ & ncertainties in the & work which & 3 & 7.69 \\
\hline 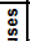 & 1. Low experience from contractor engineering & $\varnothing$ & $\varnothing$ & 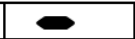 & 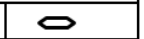 & & \\
\hline ङొ & 2. Misunderstanding of shop-Drawings and poor designers & 6 & $\varnothing$ & 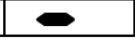 & $\varnothing$ & & \\
\hline 5 & Poorly Written Contracts Clauses & & & & & & \\
\hline 㝘 & poorly written contract clauses are incomplete because it is too costly to describe all the relevant contin & gencies and the ex & exact behavior of $\mathrm{t}$ & f the contracting $p$ & parties & & \\
\hline & 1. Diverse interpretations of contract terms. & $\sigma$ & $\varnothing$ & 6 & 6 & & \\
\hline & $\begin{array}{l}\text { 2. Other owners are more receptive to sharing the risk and use less restrictive language in their general } \\
\text { conditions }\end{array}$ & $\varnothing$ & $\varnothing$ & $\varnothing$ & $\varnothing$ & 2 & 5.12 \\
\hline & $\begin{array}{l}\text { 3. Failure to understand and or follow the requirements of the various time provisions in the contract general } \\
\text { conditions provisions. }\end{array}$ & $\boldsymbol{\sigma}$ & $\boldsymbol{\sigma}$ & $\boldsymbol{\sigma}$ & $\varnothing$ & & \\
\hline & 4. owners are not interested in dealing with increased cost or changes during construction & $\sigma$ & $\sigma$ & $\sigma$ & $\sigma$ & & \\
\hline & 5. Opportunistic behavior of project parts. & $\bar{\sigma}$ & $\bar{\sigma}$ & $\bar{\sigma}$ & $\bar{\sigma}$ & & \\
\hline & 6. Little cooperation among project parties. & $\sigma$ & $\sigma$ & $\sigma$ & $\sigma$ & & \\
\hline 6 & Change Orders & & & & & & \\
\hline 㝘 & $\begin{array}{l}\text { A change is defined as any deviation from an agreed upon well-defined scope and schedule. Stated differently a c } \\
\text { the contractor by the owner or owner's representative. This includes changes to plans, spe }\end{array}$ & $\begin{array}{l}\text { hange is any mod } \\
\text { ecifications or any }\end{array}$ & $\begin{array}{l}\text { dification to the co } \\
\text { y other contract d }\end{array}$ & $\begin{array}{l}\text { contractual guidar } \\
\text { document }\end{array}$ & nce provided to & & \\
\hline & e- Progress is affected but without any delay & $\sigma$ & $\sigma$ & $\sigma$ & $\sigma$ & & \\
\hline & 1. Increase in project cost & $\bar{\sigma}$ & $\bar{\sigma}$ & $\bar{\sigma}$ & $\bar{\sigma}$ & 3 & 7.69 \\
\hline 站 & 2. Delay in payment & $\bar{\sigma}$ & $\bar{\sigma}$ & $\bar{\sigma}$ & $\sigma$ & & \\
\hline 㓂 & 3. Procurement delay & $\sigma$ & $\sigma$ & $\sigma$ & $\sigma$ & & \\
\hline & 4. Rework and demolition & $\sigma$ & $\sigma$ & $\sigma$ & $\sigma$ & & \\
\hline & 5. Poor safety conditions & $\sigma$ & $\sigma$ & $\sigma$ & $\sigma$ & & \\
\hline 7 & Co-Operation \& Communication Nature Among Proj & ect Team & & & & & \\
\hline 㝘 & $\begin{array}{l}\text { construction project depends heavily upon the timely and traditional transfer of information such as face to face me } \\
\text { paper documents. Therefore, good communication needs to be established from the start in orde }\end{array}$ & $\begin{array}{l}\text { eetings, phone call } \\
\text { er to prevent the pr }\end{array}$ & $\begin{array}{l}\text { alls and the exchar } \\
\text { broblems escalatir }\end{array}$ & $\begin{array}{l}\text { ange of drawings } \\
\text { ting into disputes }\end{array}$ & and associated & 1 & 5 \\
\hline \& & 1. Denying access to the project by owner & $\varnothing$ & $\varnothing$ & $\sigma$ & $\sigma$ & 1 & 2.56 \\
\hline 䍖 & 2. Using the site in a way that impedes the contractor's work at the site by owner & $\sigma$ & $\sigma$ & $\sigma$ & $\sigma$ & & \\
\hline ¿ & 3. Allowing other contractors to work on the project site in a way that interferes with the contractor's work. & $\sigma$ & 6 & $\sigma$ & $\sigma$ & & \\
\hline 8 & Late Supply Of Equipment And Mateerials & & & & & & \\
\hline 覀 & $\begin{array}{l}\text { factors of material and e related delays the poor quality of material and shortage having high influence to causes } \\
\text { construction, delay in material delivery, damage of sorted material while }\end{array}$ & $\begin{array}{l}\text { So delays, chang } \\
\text { they are needed u }\end{array}$ & $\begin{array}{l}\text { ges in material ty } \\
\text { urgently }\end{array}$ & ypes and specific & cations during & & \\
\hline & 1. Shortage of construction materials in market & $\sigma$ & $\sigma$ & $\sigma$ & $\sigma$ & & \\
\hline & 2. Unpunctually material delivery. & $\bar{\sigma}$ & $\bar{\sigma}$ & $\bar{\sigma}$ & $\bar{\sigma}$ & 4 & 1025 \\
\hline & 3. Poor quality of material in construction & $\sigma$ & $\sigma$ & $\sigma$ & $\sigma$ & 4 & 10.25 \\
\hline (1) & 4. Spend more time to replace or repair equipment parts by sub suppliers & $\sigma$ & $\sigma$ & 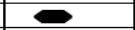 & $\sigma$ & & \\
\hline 苞 & 5. Tight contact with supplier & $\bar{\sigma}$ & $\sigma$ & $\sigma$ & $\sigma$ & & \\
\hline & 6. changes in material types and specifications & $\bar{\sigma}$ & $\bar{\sigma}$ & $\bar{\sigma}$ & $\bar{B}$ & & \\
\hline & 7. Damage of sorted material while they are needed urgently & $\sigma$ & $\sigma$ & $\sigma$ & $\theta$ & & \\
\hline & 8. Low level of equipment-operator's skill & $\bar{\rho}$ & $\bar{\sigma}$ & $\bar{\sigma}$ & $\bar{\sigma}$ & & \\
\hline & & & & & Total & 39 & \\
\hline
\end{tabular}

